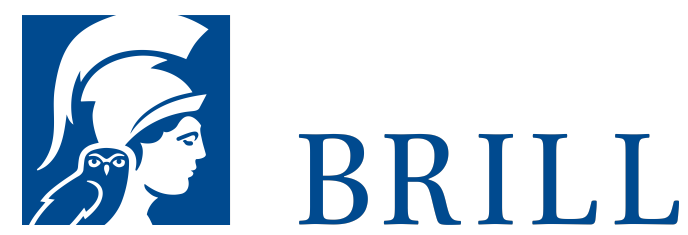

\title{
August Wilhelm Schlegel
}

Biografie

Author: Roger Paulin

Zum ersten Mal liegt mit der Biographie August Wilhelm Schlegels (1767-1845) eine umfassende Würdigung dieser herausragenden Persönlichkeit der deutschen und europäischen Romantik vor. Roger Paulin, ein renommierter Kenner dieser Epoche, zeichnet versiert und kurzweilig die Lebensgeschichte dieses vielseitig interessierten und talentierten $>$ Kosmopoliten der Kunst und Poesie $<$ nach: Schlegel war Poet, Übersetzer zahlreicher Sprachen, Literaturkritiker und Wissenschaftler und wirkte vielfach als Initiator neuer Strömungen und Denkrichtungen. Gemeinsam mit seinem Bruder Friedrich, mit dem er die avantgardistische Zeitschrift Athenaeum herausgab, gilt er als Initiator der literarischen Romantik. Besonders bekannt wurde er durch die Übersetzung von Shakespeares Werken: Zum ersten Mal wurde Shakespeare durch ihn und seine Frau Caroline in Versform in eine fremde Sprache übertragen. Paulin eröffnet mit seiner fulminanten Biographie faszinierende Einsichten in das Leben und Werk eines Universalgenies und sein namhaftes Milieu und zeichnet zugleich das Panorama einer Epoche.

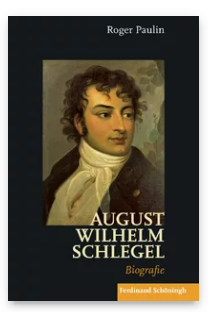

Pages: 370

Seiten

Language:

German

Subjects:

German,

Literature and

Cultural Studies

Publisher: Brill |

Schöningh

E-Book (PDF)

Released online: 17 Nov 2017

ISBN: 978-3-

657-78437-0

List price

Hardback

Publication date: 29 Sep 2017

ISBN: 978-3506-78437-7

List price 
Roger Paulin war bis zu seiner Emeritierung 2005 Professor für Germanistik an der Universität Cambridge. Er ist Autor zahlreicher Veröffentlichungen zu Goethe, der Romantik und zur Shakespeare-Rezeption. 2002 erhielt er den Forschungspreis der Alexander von Humboldt-Stiftung.

For more information see brill.com

Order information: Order online at brill.com +44330 333 oo49 | customerservices@brill.com Submission information: brill.com/authors

Titles published by Brill | Fink, Brill | mentis or Brill | Schöningh: +49(o)715413279216| brill@brocom.de 